\title{
偏心接合される塔状鋼管トラス骨組の構造特性に関する研究 \\ STUDY ON STRUCTURAL CHARACTERISTICS OF TUBULAR STEEL TRUSSED TOWERS WITH ECCENTRIC CONNECTIONS
}

\author{
本郷 榮次郎*, 深 沢 隆**, 松 尾 康 博***, 田沼 良一***, 岡田 創*** \\ Eijiro HONGO, Takashi FUKASAWA, Yasuhiro MATSUO, \\ Yoshikazu TANUMA and Hajime OKADA
}

\begin{abstract}
The present paper discusses structural characteristics of the tubular steel trussed tower with gusset plate typed connections, specially having an eccentric joint applied to the crossing between column and braced members. Firstly, it is clarified effects of eccentric bending moment to the column buckling strength by horizontal loading tests and non-linear analyses for the model planned to make its column member buckle at first. Secondary, it is discussed effects of local deformation of the column tube at the eccentric joint to static and fatigue bearing strength of its connection. Lastly, based on results of the present study, it has been authorized fundamental data for the practical design in case of application of the eccentric joint to such the steel tower.
\end{abstract}

Keywords:tubular steel trussed tower, eccentric connection, structural characteristics 塔状鎙管トラス骨組，偏心接合，構造特性

\section{1. 落司}

送電用銅管トラス鉄塔の柱材一腹材接合部には, Fig.1に示すよう に，柱材に隅肉溶接されるガセットプレートと腹材端部に隅肉溶接 される管ガセットプレートをせん断ボルト接合する方式が用いられ ている。この接合部は，特に腹材傾斜角度 $\theta_{\mathrm{b}}$ が大きい場合，ガセッ トプレート長さの柱材節点間長さに対する比が大きくなり，製作し にくい等の問題点が生ずる。これを改善する方法の一つとして，腹 材を内側に偏心接合させる方法が考えられる。

この偏心接合を，主に送電用鋼管トラス鉄塔に適用する際には，(1)偏 心曲げモーメントの柱材座屈耐力に及ぼす影響の把握。(2)柱材一腹材偏 心接合部の局部変形耐力評価(以下，接合部而力之呼3)，(3)柱材一腹材偏 心接合部まわりの疲労耐力評価，等の諸課題が挙げられる。

偏心接合される部材は，各節点をピンとして算定した軸力と，節点に 作用する偏心曲げモーメントを節点に集まる部材の剛性に比例する形て 分配することにより算定した曲げモーメントを考虑して設計されるのが 一般的であり，送電用鉄塔のように強度設計されるトラス骨組構成部材 の座屈耐力については，偏心の有無に関わらす研究的余地はほとんど残 されていないものと考えられている。したがって，トラス骨組に関 しては，重層骨組を対象とした塑性変形能力に着目した研究が主流 となっており，本研究対象の偏心接合を有する骨組の座屈耐力に関 する実験的研究例は極めて少ないのが実状である。

しかしながら，偏心曲げモーメントの柱材の座屈耐力に及ぼす影
響を定量的に把握しておくことは，骨組を設計するにあたって不可 欠であると考える。

銅管トラスの接合部耐力については，分岐継手を対象とした多く の研究が行われている。本研究対象のガセットプレート接合タイプ についても分岐継手に比へて研究例は少ないものの, 日本建筑学会 銅管構造設計施工指針・同解説 1),2)に単位作用力ことの設計式が明 示されており、これを組合せることにより設計することができる。しか しながら，偏心曲げモーメントを実際のティテールで作用させた研究は ほとんど行われておらず，上設計式の適合性を確認する必要がある。 また，鋼管トラス接合部の疲労特性については，分岐継手を対象
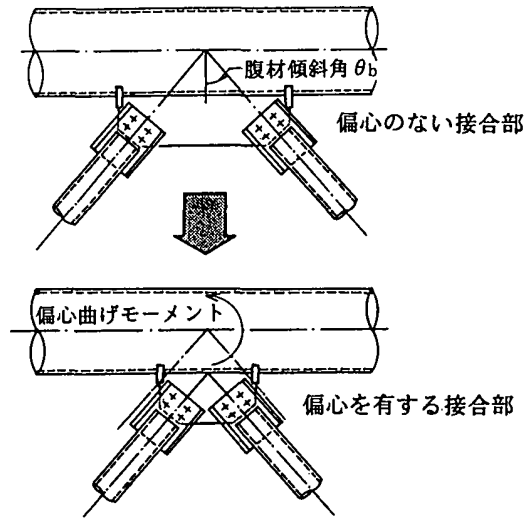

Fig.1 偏心接合部適用概念図

\footnotetext{
本論文の概要については, 文献6)に発表済

* 東京電力侏

***侏巴コーポレーション I博

*** (侏巴コーポレーション
} 
に多くの研究が行われ，文献 1),2)に溶接部止端形状に起因する応力 集中以外に管壁の局部曲げによる応力集中屯考慮した設計方法が提 案されている。しかしながら，本研究対象のガセットプレート接合 タイプについての研究報告は筆者らの知る限りにおいてはなされて おらず，特に送電鉄塔のように風荷重が支配的な外力となる場合に は避けては通れない問題であることから、この疲学特性の定量的な 把暒が必要と考える。

以上，ガセットプレート接合タイプの送電用鉄塔に代表される塔 状錝管卜ラス骨組に偏心接合を適用するにあたっては，これらの諸 課題を解決する必要がある。本研究は, 以上三つの課題を実験的に 明らかにし，設計基礎デー夕の整備を図ることを目的とするものである。

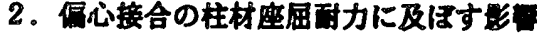

\section{1 柱材座屈而力試験概要}

試験体は, Fig.2の構造図に示すように，塔高 $6.75 \mathrm{~m}$ ，根開き $2.4 \mathrm{~m}$, 柱材傾斜角度 $\theta_{\mathrm{p}}=3.5$ 度と形状寸法を共通とし, 座屈予想パネル柱材 の腹材に対する軸力比 $\mathrm{N}_{\mathrm{p}} / \mathrm{N}_{\mathrm{b}}$ が 10 程度(送電用鉄塔における下限相 当値であり， $\mathrm{N}_{\mathrm{p}} / \mathrm{N}_{\mathrm{b}}$ が小さい程偏心曲げモーメントは大きい)となる ように試験体上部に高さ $4.0 \mathrm{~m}$ の載荷用骨組を取付ける。

座屈耐力に影響を及ぼすファクターは，(1)骨組形式としてDW(タ ブルワーレン)骨組(腹材傾斜角度 $\theta_{\mathrm{b}}=40^{\circ}$ ), さらに柱材を 2 分割し たDW 2 骨組 $\left(\theta_{b}=50^{\circ}\right) ４$ 分割したDW 4 骨組 $\left(\theta_{b}=50,60^{\circ}\right) の 4$ 種 類, (2)柱材一腹材接合部の偏心の有無(偏心無し, 内側 $\mathrm{D} / 2$ 偏心)とし 試験体総数はこれを組み合わせた Table 1 に示す 7 体とする。この とき，座屈予想柱材細長比 $\lambda$ p はDW骨組では 45, DW 2 骨組では 24, D W 4 骨組では 14，22 となる。
使用鋼材は，柱材には JS G 3474 鉄塔用高張力鋼管 STKT590 鋼 管，腹材，補助材にはSTK400 鋼管，腹材に取付く鋼板には JS G 3129 鉄塔用高張力鋼材 SH590P，それ以外の鋼板にはSS400 を用いる。なお， 試験体の全ての構成要素には溶融亜鉛めっき処理が施される。Table 2 に座屈部材の材料引張試験結果および短柱圧縮試験結果を示す。

Fig. 3 に -2 試験体の詳細図を示す。なお, 柱材に取り付くガセ ットプレート端部は半円リングスチフナで補強される。ティテール は文献 3)に詳説される。

載荷は, Fig.4に示すように, 試験骨組を反力壁に横に取り付け, 試験骨組頭部載荷用骨組頂部に油圧ジャッキを用いて，骨組に対す る正対方向(載荷方向 $0^{\circ}$ ) に水平力 $\mathrm{P}$ を作用させる方法で行う。

\section{2 . 2 柱材の偏心率分布}

一般にトラス部材に生じる応力は, 節点をピン接合として扱って 応力を算定することから，ローカル曲げモーメントを除けば軸力 $\mathrm{N}$ のみとなるが，本研究では，文献 3)をはじめとした塔状トラス骨組 を対象とする研究において，実験結果との比較により既に有効性が 確認されている，Fig.5に示す，柱材両端部，左下がり腹材中央交点

Table 2 材料引張，短柱圧縮試験結果

\begin{tabular}{|c|c|c|c|c|c|}
\hline (材 實) & 別 & $\begin{array}{c}\text { 降 伏 } \\
\text { 応力度 } \\
\sigma \text { y } \\
\left(\mathrm{t} / \mathrm{cm}^{2}\right)\end{array}$ & $\begin{array}{c}\text { 強 } \\
\begin{array}{c}\sigma \\
\sigma u \\
\left(t / \mathrm{cm}^{2}\right)\end{array} \\
\end{array}$ & $\begin{array}{l}\text { 降伏比 } \\
\text { 底吕 } \\
\text { 上昇芼 }\end{array}$ & $\begin{array}{c}\text { 伸 び } \\
(\%) \\
\varepsilon \cup(\%)\end{array}$ \\
\hline \multirow{2}{*}{$\begin{array}{c}\phi 114.3 \times 3.5 \\
(\text { STKT590) }\end{array}$} & $\mathrm{T}$ & 6.34 & . & 0.93 & 22.0 \\
\hline & c & 6.83 & 6.83 & 1.00 & 0.5 \\
\hline
\end{tabular}

1) $\varepsilon$ u： $\sigma$ uに対応するひずみ

材料引張武験はJIS Z 2241に規定される践倹方法による。

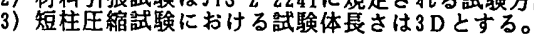
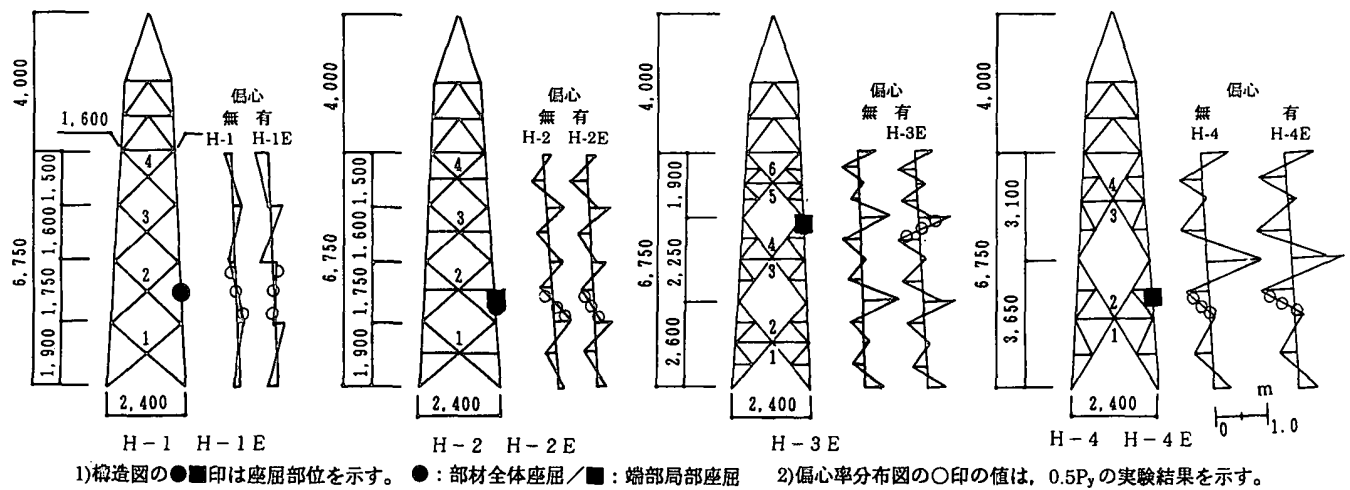

Fig.2 骨組試験体構造図, 偏心率分布図

Table 1 骨組試験体諸元

\begin{tabular}{|c|c|c|c|c|c|c|c|c|c|c|}
\hline \multirow{2}{*}{$\begin{array}{l}\text { 試 験体 } \\
\text { 名 称 }\end{array}$} & \multicolumn{3}{|c|}{ 座 屈 柱 材 } & \multicolumn{4}{|c|}{ 座屈パネル腹材 } & \multirow{2}{*}{\begin{tabular}{|l} 
接合部 \\
偏心昌
\end{tabular}} & \multicolumn{2}{|c|}{ 実施事項 } \\
\hline & サ1 ス & 細長比 & 座屈部位 & 結 標 & サ1 ス & 細長比 & 傾斜角度 & & 実験 & 解析 \\
\hline $\mathrm{H}-1$ & \multirow{7}{*}{$\phi 114.3 \times 3.5$} & \multirow{2}{*}{45} & \multirow{2}{*}{2 中央部 } & \multirow{2}{*}{ DW } & \multirow{2}{*}{$\phi 42.7 \times 2.4$} & \multirow{2}{*}{82} & \multirow{2}{*}{$40^{\circ}$} & 0 & 0 & \\
\hline $\mathrm{H}-1 \mathrm{E}$ & & & & & & & & $\mathrm{D} / 2$ & & 0 \\
\hline $\mathrm{H}-2$ & & \multirow{2}{*}{24} & $2 下$ 中央部 & \multirow{2}{*}{ DW2 } & \multirow{2}{*}{$\phi 48.6 \times 2.4$} & \multirow{2}{*}{79} & \multirow{2}{*}{$40^{\circ}$} & 0 & 0 & \\
\hline$H-2 E$ & & & 2 下 上端部 & & & & & $\mathrm{D} / 2$ & 0 & \\
\hline$H-3 E$ & & 14 & 4 上 上端部 & \multirow{3}{*}{ DWH4 } & $\phi 42.7 \times 2.3$ & 39 & $50^{\circ}$ & $\mathrm{D} / 2$ & 0 & \\
\hline $\mathrm{H}-4$ & & \multirow{2}{*}{22} & 2 下 上端部 & & \multirow{2}{*}{$\phi 60.5 \times 2.3$} & \multirow{2}{*}{43} & \multirow{2}{*}{$60^{\circ}$} & 0 & 0 & \\
\hline $\mathrm{H}-4 \mathrm{E}$ & & & 2 上 上端部 & & & & & $\mathrm{D} / 2$ & 0 & \\
\hline
\end{tabular}

1)座屈部位は压縮㑡局部座屈発生简所を示す。また，数字はパネル番号(Fig. 2参照)を示す。

2)骨組結構における記号は本文中の記述に做う。3)腹材細長比は座屈長さ係数0.9として算定。

4)偏心区は柱材一腹材接合部の值を示す。このとき，十符号は内僛引き付けを，Dは柱材銅管径を示す。 
端部は通し材として扱うことにより剛, その他の部材端はピン, 柱 脚剛, 偏心接合部は偏心量に相当する長さの剛体置換の, 実態に即 した境界条件を用いた立体応力解析結果に基つく応力を基本とする。 したがって，偏心がない場合においても，柱材には曲げモーメント が生じることとなる。なお，曲げモーメントMは 2 方向の自乗和とする。

Fig.2 に上記立体応力解析に基づく柱材偏心率分布を示す。ここに， 偏心率 $\mathrm{m}$ は(1)式より与えられる。

$$
\mathrm{m}=\frac{\mathrm{e}_{0} \mathrm{D}}{2 \mathrm{i}^{2}}
$$

$\mathrm{e}_{0}$ : 偏心距離 $(=\mathrm{M} / \mathrm{N})$, この值は偏心量 $\mathrm{e}$ とは異なる。

$\mathrm{N}, \mathrm{M}:$ 軸力, 曲げモーメント

$\mathrm{D}$ : 鋼管外径, $\mathrm{i}$ : 断面 2 次半径

これより，図中○印で示す座屈部材の弾性領域 $\left(0.5 \mathrm{P}_{\mathrm{y}}\right)$ におけるゲ 一シ貼付位置での実験結果は, 実線で示す解析結果と良い対応を示 していることがわかる。

Fig.6に各パネルにおける柱材最大偏心率 $\mathrm{m}_{\max }$ と腹材傾斜角 $\theta_{\mathrm{b}}$ の 関係を示す。これより，偏心接合の有無に関わらず，腹材傾斜角度 が大きいほぼ水平力に対する腹材剛性が低下し，相対的に柱材の曲 け抵抗負担が大きくなるため，偏心率 $\mathrm{m}$ も大きくなる傾向にある。また， Fig.7 に示すように, 節点片側では部材が連続材であることによって生ず る值に偏心の影響が重畳されることから，偏心のない場合に比べて偏心 率は大きくなる傾向にあるが，その程度は小さいと判断される。

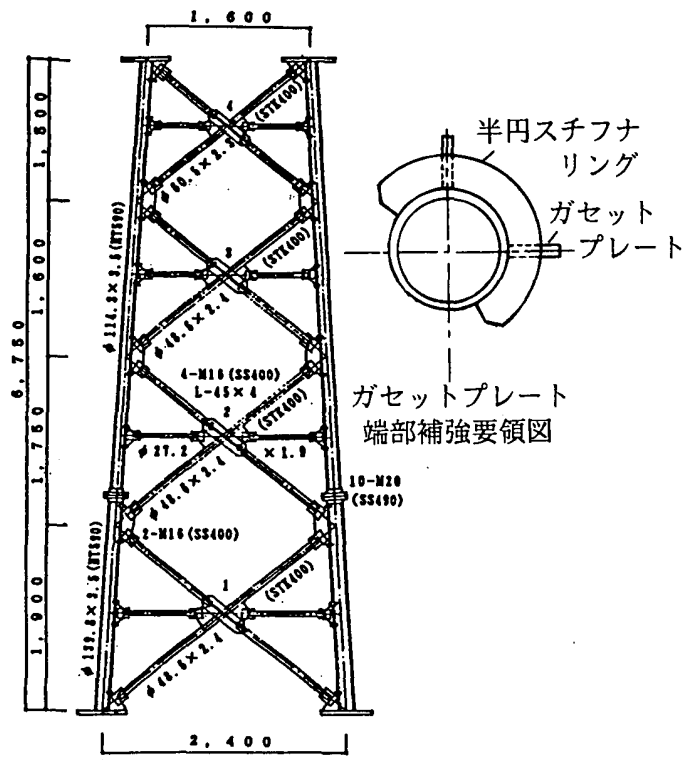

Fig.3 骨組試験体詳細図(H-2)

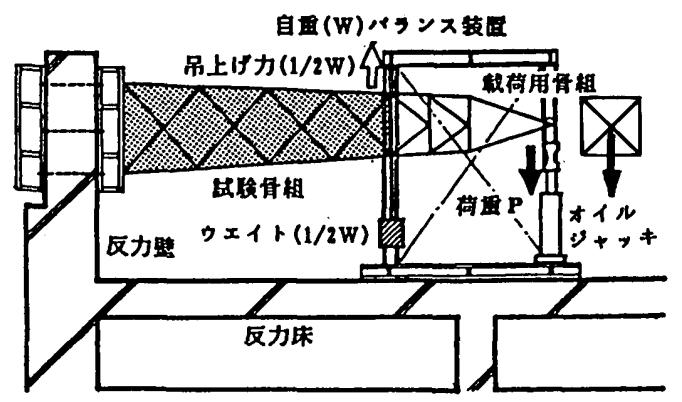

Fig.4 骨組試験装置図

\section{2 ． 3 骨組の座屈変形挙動}

Fig. 8 に荷重 $\mathrm{P}$-試験骨組頂部荷重方向变形 $\delta$ 関係曲線を示す。こ こに，実験結果を図中実線および点線で，短柱圧縮試験における応 力度一ひずみ度関係曲線を用いた非線形解析3)結果をプロット点て 示す。また，縦軸は弾性応力解析において座屈部材が降伏軸力 $\mathrm{N}_{\mathrm{y}}$ に 達する時の荷重 $\mathrm{P}_{\mathrm{y}}$ で, 横軸は $\mathrm{P}_{\mathrm{y}}$ に対応する弾性変形量 $\delta_{\mathrm{y}}$ てそれぞ れ無次元化している。

これより，いずれの試験体も，ほぼ線形挙動領域とみなせる図中 $\nabla \nabla$ 印(黒㓌り:実験結果,白抜き:解析結果)で示す荷重レベルては $0.83 \sim 0.95 \mathrm{P}_{\mathrm{y}}$ ，変形レベルては $1.0 \delta_{\mathrm{y}}$ 近傍において座屈屈伏し， 耐力低下を来す。座屈箇所は Fig.2 図中の骨組結構図において○印 で示す箇所であり, DW $(\mathrm{H}-1, \mathrm{H}-1 \mathrm{E})$, 偏心無しのDW 2 骨組 $(\mathrm{H}$ $-2)$ では部材の全体的な曲げ座屈, 偏心有りの DW $2(\mathrm{H}-2 \mathrm{E})$, DW 4 骨組 $(\mathrm{H}-3 \mathrm{E}, \mathrm{H}-4, \mathrm{H}-4 \mathrm{E})$ では，曲げモーメントの影響 によりガセットプレート，スチフナ等で補強された接合部外側で局 部座屈を呈する。

DW 4 骨組においては，座屈発生箇所での偏心率にこで，スチ フナフェイス位置で解析值とする。なお，実験值との対応は確認 している)が $0.3 \sim 0.5$ と大きく, かつ柱材細長比が 22 と小さいこと から，Fig.93)に模式的に示すように，圧縮部材の全体的な曲け座屈 ではなく，曲げモーメントの影響による端部圧縮側降伏で耐力が決 定される。ちなみに， H-4 E はH - 4 に比へて，座屈発生箇所に

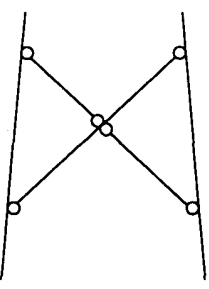

偏心無しの場合

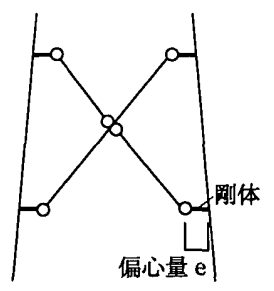

偏心有りの場合 Fig.5 解析に用いる境界条件概念図

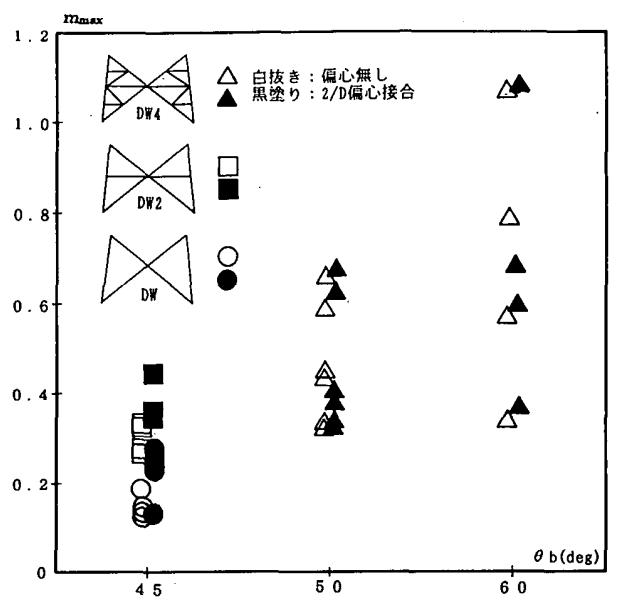

Fig.6 偏心率一腹材傾斜角度関係

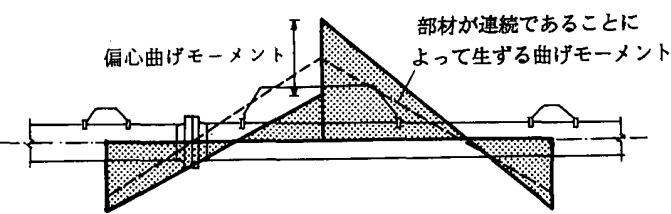

Fig.7 偏心曲げモーメント概念図 

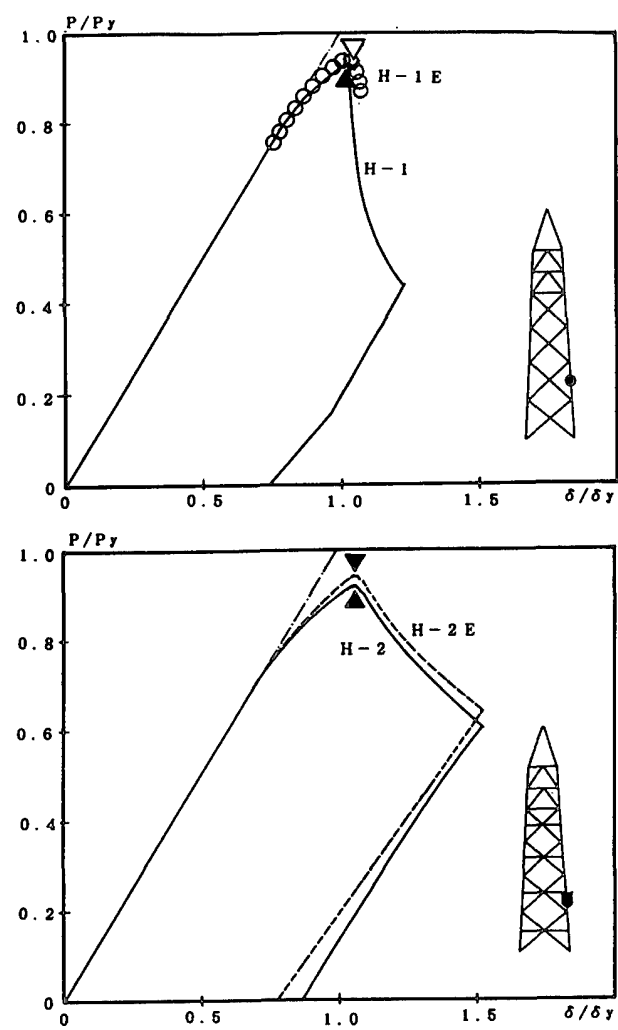
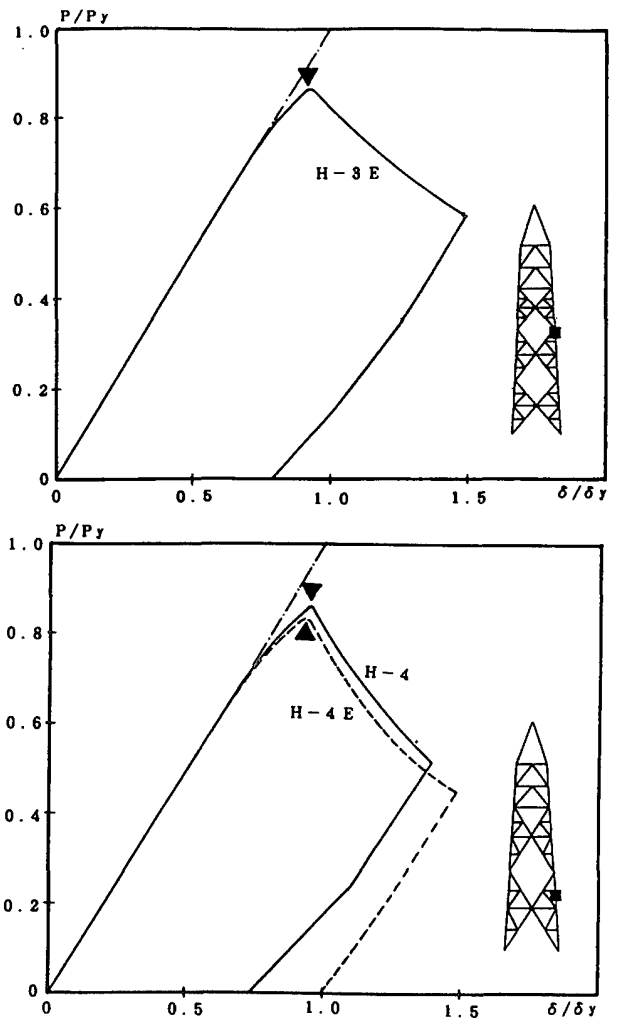

Fig.8 荷重一試験体頂部変形関係

おける曲げモーメントは概ね $50 \%$ 程度大きく, 耐力は $3 \%$ 程度小さく なる結果となる。

DW 2 骨組において，H-2 と H- 2 E は座屈モードが異なるか， 耐力面での大きな差異は認められない。これは, 座屈発生箅所での 偏心率が 0.15 0.2 と小さく，座屈耐力に及ぼす影響が小さいことに よる。

DW骨組では，柱材細長比が 45 と比較的大きいことから全体的な 曲げ座屈で屈伏し，部材単位でみた埸合，逆対称で端部で大きくな る分布となる曲げモーメントの影響を受けない結果となる。

これより，本研究の範囲においては，DW 骨組で $3 \%$ 程度の耐力低 下はあったものの，総じて，偏心接合による著しい耐力低下は認め られないこと，また荷重－変形関係，特に座屈耐力時の変形量ある いは劣化勾配に及ほす影響は，座屈柱材の細長比の影響が支配的て あり，编心の有無あるいは座屈部位，モードの影響はほとんど見受 けられないことが確認される。

\section{4 柱材座屈耐力の定量的評価}

局部座屈した部材の耐力算定位置は実験結果との対応より，ガセ ットプレート，スチフナ等で補強される領域を剛域とみなしたスチ フナフェイス位置とする。このとき，既往の研究結果 3)より曲げモ 一メントによる耐力低下率 $\alpha_{1}$ は(2)式を用い算定する。また, 細長 比の影響は考虑しない。

$$
\alpha_{1}=\frac{2}{\pi} \cos ^{-1}\left(\frac{\mathrm{M}}{\mathrm{M}_{\mathrm{p}}}\right)
$$

$$
\mathrm{M}_{\mathrm{p}} \text { : 全塑性曲げモーメント }
$$

一方，曲げ座屈する場合の細長比による耐力低下率 $\alpha 2$ は(3) 式を用い，また曲げモーメントによる耐力低下は，(2)式に部材

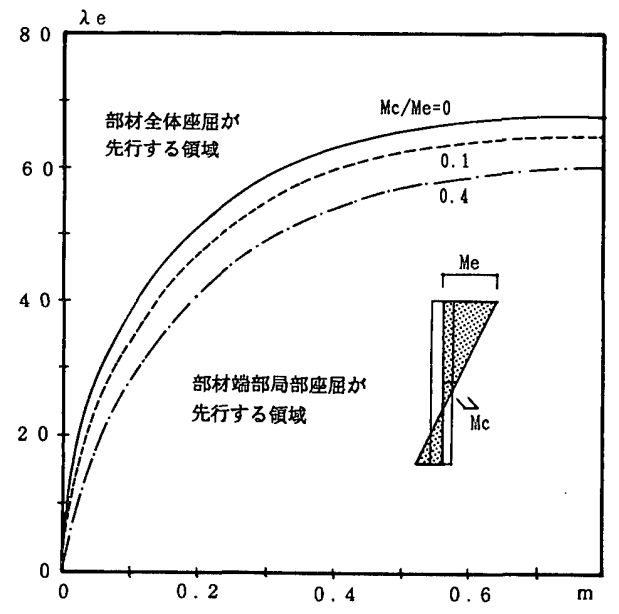

Fig.9 有効細長比一偏心率関係

中央部の局部座屈発生简所における值を代入することにより算 定する。

$$
\begin{aligned}
\alpha_{2}=\frac{\pi^{2} E}{\lambda e^{2} \sigma_{y}}\left[1-\left\{\frac{\left(\alpha_{2}-\beta\right)}{(1-\beta)}\right\}\right] \\
\beta: \text { ぬっき鉿管の場合 }=0.8 \\
\sigma_{y}: \text { 降伏応力度 } \\
\lambda_{\mathrm{e}}: \text { 有効細長比 }(=0.5 \lambda)
\end{aligned}
$$

このとき, 各部の耐力を同一荷重 $\mathrm{P}_{0}$ 時の軸力で除した値(=座屈安 全率)が最も小さい部位で座屈が生ずる。

Table 3 に座屈耐力に関する上記評価による算定結果と実験結果 との比較表を示す。これより，両者は概ね良い一致をみており，算 定方法の有効性か確認される。 


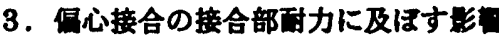

3. 1 接合部耐力試験概要

鋼管接合部の耐力に影響を及ぼすファクターとしては, (1)偏心量 $\mathrm{e}$ として外側偏心-D/2, -D/4, 偏心無し, 内側偏心 $\mathrm{D} / 4, \mathrm{D} / 2$ の 5 種類, (2)ガセットプレート端部補強方法として補強無し(G シリーズ), サド ル型スチフナ(SA シリーズ), 半円スチフナ(SB シリーズ)の 3 種類と し，試験体総数はこれらを組合わせた Table 4 に示す 12 体とする。

柱材は， $\phi 139.8 \times 3.5($ STKT590)一定值，柱材に隅肉溶接される ガセットプレートは PL-9(SH590P), 補強プレートは PL-6(SH590P),
また腹材は加力ロッド扱いとする。Fig.10 に接合部の詳細図を， Table 5 に材料引張試験結果を示す。

Fig.11 に示すように，柱材は下端は移動固定，上端は材軸方向に 移動自由とし，それぞれ構面内に回転自由の境界条件とする。載荷 は，水平方向 $\pm 45^{\circ}$ 方向に配された 2 台のアクチュエーター・加力 ロッド(腹材に相当)により，絶対值が等しく水平方向成分が相殺され る方向の軸力 $\mathrm{P}$ を作用させる。なお, アクチュエーターと加力ロッ ドおよび加カロッドとガセットプレート取合部は構面内に回転自由 とし，接合部の回転変形を拘束しない形とする。

Table 3 骨組試験結果一覧表

\begin{tabular}{|c|c|c|c|c|c|c|c|c|}
\hline \multirow{2}{*}{ 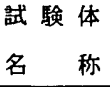 } & \multicolumn{3}{|c|}{$\alpha_{2}$ の算定 } & \multicolumn{2}{|c|}{$\alpha, の$ 算定 } & \multirow{2}{*}{ (1) $\alpha_{1} \alpha_{2}$} & \multirow{2}{*}{ (2) ${ }_{\mathrm{Py}}^{\mathrm{Pcr}}$} & \multirow{2}{*}{ (2) } \\
\hline & $\lambda$ & $\lambda \mathrm{e}$ & $\alpha_{2}$ & $\mathrm{~m}$ & $\alpha$, & & & \\
\hline $\mathrm{H}-1$ & \multirow{2}{*}{45} & \multirow{2}{*}{22} & \multirow{2}{*}{0.980} & 0.063 & 0.970 & 0.94 & 0.93 & 0.99 \\
\hline$H-1 E$ & & & & 0.002 & 0.995 & 0.97 & 0.95 & 0.98 \\
\hline$H-2$ & 24 & 12 & 0.995 & 0.171 & 0.925 & 0.92 & 0.92 & 1.00 \\
\hline$H-2 E$ & (24) & 0 & 1.000 & 0.180 & 0.920 & 0.92 & 0.94 & 1.02 \\
\hline$H-3 E$ & (14) & 0 & 1.000 & $\begin{array}{c}0.368 \\
{[0.173]}\end{array}$ & $\begin{array}{c}0.845 \\
{[0.925]}\end{array}$ & $\begin{array}{c}0.85 \\
{[0.93]}\end{array}$ & 0.86 & 1.01 \\
\hline$H-4$ & \multirow{2}{*}{ (22) } & \multirow{2}{*}{0} & \multirow{2}{*}{1.000} & 0.336 & 0.860 & 0.86 & 0.86 & 1.01 \\
\hline $\mathrm{H}-4 \mathrm{E}$ & & & & 0.484 & 0.805 & 0.81 & 0.83 & 1.04 \\
\hline
\end{tabular}

1) $\lambda$ は座屈柱材の細長比であり，中央部全体座屈の場合は無印，端部局部座屈の場合は（）付で示す。

2) $\lambda$ 日仕有効細長比であり, 全体座屈の場合は $1 / 2 \lambda$, 局部座届の場合は 0 とする。

3) P c r は実験あるいは解析における座屈耐力を示す。

4) $\mathrm{H}-3 \mathrm{E} の[]$ 内の值は偏心のない場合の值を示す。

Table 4 接合部耐力試験体諸元

\begin{tabular}{|c|c|c|c|c|c|c|}
\hline 式験体 & $\begin{array}{l}\text { ガセット } \\
\text { 端部補強 }\end{array}$ & $\begin{array}{c}\text { 偏心量 } \\
\mathrm{e}\end{array}$ & $\underset{(\mathrm{mm})}{\mathrm{B}}$ & $\underset{(t)}{P \max }$ & $\begin{array}{c}p P \operatorname{Pr} \\
(\mathrm{t})\end{array}$ & $\begin{array}{l}\mathrm{g} P \mathrm{P} \\
(\mathrm{t})\end{array}$ \\
\hline $\begin{array}{ll}G & 3 \\
G & 5\end{array}$ & $\begin{array}{l}\text { 補強なし } \\
(\mathrm{C}=0)\end{array}$ & $\begin{array}{c}0 \\
D / 2\end{array}$ & $\begin{array}{l}350 \\
210\end{array}$ & $\begin{array}{l}32.5 \\
44.7\end{array}$ & $\begin{array}{l}68.1 \\
46.6\end{array}$ & $\begin{array}{l}79.2 \\
47.5\end{array}$ \\
\hline $\begin{array}{l}\text { SA } 1 \\
\text { SA } 2 \\
\text { SA } 3 \\
\text { SA } 4 \\
\text { SA } 5\end{array}$ & $\begin{array}{l}\forall \begin{array}{r}* \\
\pi チ フ+ \\
(C=40)\end{array} \\
(C=4\end{array}$ & $\begin{array}{c}-D / 2 \\
-D / 4 \\
0 \\
D / 4 \\
D / 2\end{array}$ & $\begin{array}{l}490 \\
420 \\
350 \\
280 \\
210\end{array}$ & $\begin{array}{l}24.0 \\
27.4 \\
35.6 \\
52.3 \\
46.1\end{array}$ & $\begin{array}{l}49.2 \\
56.9 \\
68.1 \\
56.1 \\
46.6\end{array}$ & $\begin{array}{r}110.8 \\
95.0 \\
79.2 \\
63.3 \\
47.5\end{array}$ \\
\hline $\begin{array}{l}\text { S B } 1 \\
\text { S B } 1 \\
\text { S B } \\
\text { S B } \\
\text { S B } 4 \\
\text { S B } 5\end{array}$ & $\begin{array}{l}\text { 半 P } \\
\text { スチフナ } \\
(C=99)\end{array}$ & $\begin{array}{c}-D / 2 \\
-D / 4 \\
0 \\
D / 4 \\
D / 2\end{array}$ & $\begin{array}{l}490 \\
420 \\
350 \\
280 \\
210\end{array}$ & $\begin{array}{l}43.2 \\
51.0 \\
59.2 \\
56.4 \\
49.3\end{array}$ & $\begin{array}{l}49.2 \\
56.9 \\
68.1 \\
56.1 \\
46.6\end{array}$ & $\begin{array}{r}110.8 \\
95.0 \\
79.2 \\
63.3 \\
47.5\end{array}$ \\
\hline
\end{tabular}

1) $\mathrm{P} \max :$ 実験における最大耐力

$\mathrm{p} P \mathrm{cr}$ ：柱材ガセットブレート端部位置の座屈耐力算定値 g Py : ガセットプレートせん断降伏耐力

Table 5 材料引張試験結果

\begin{tabular}{|c|c|c|c|c|}
\hline 試 験 体 & $\begin{array}{c}\text { 降 伏 } \\
\text { 応力度 } \\
\sigma y \\
(t / c m 2) \\
\end{array}$ & 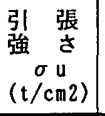 & $\begin{array}{c}\text { 降伏比 } \\
\text { Y.R. }\end{array}$ & $\begin{array}{l}\text { 伸 } \mho \\
\varepsilon \max \\
(\%)\end{array}$ \\
\hline $\begin{array}{ll}\phi 139.8 \times 3.5 \\
\text { Gusset } & P L-9 \\
\text { Stiffner } & \text { PL-6 }\end{array}$ & $\begin{array}{l}6.43 \\
5.54 \\
6.00\end{array}$ & $\begin{array}{l}7.04 \\
6.00 \\
6.39\end{array}$ & $\begin{array}{l}0.93 \\
0.92 \\
0.94\end{array}$ & $\begin{array}{l}23.0 \\
18.0 \\
15.0\end{array}$ \\
\hline
\end{tabular}

1) 材料引張檬験はJIS Z 2241に規定される試跧方法による。
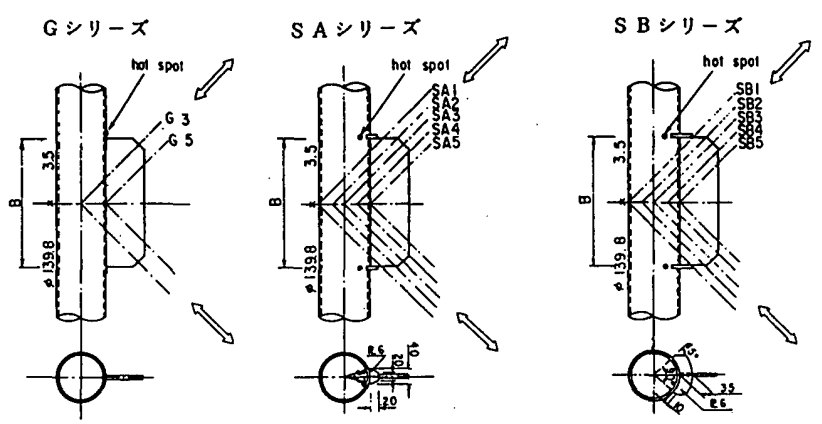

Fig.10 接合部耐力試験体部分詳細図

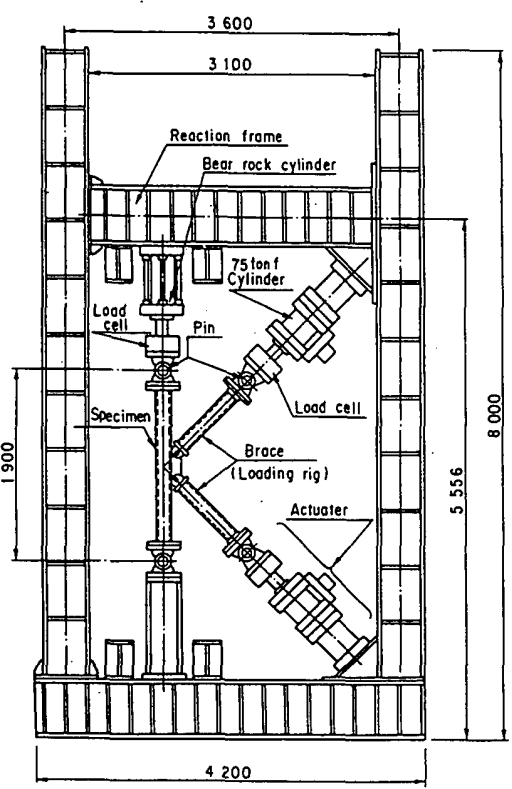

Fig.11 接合部耐力試験装置図
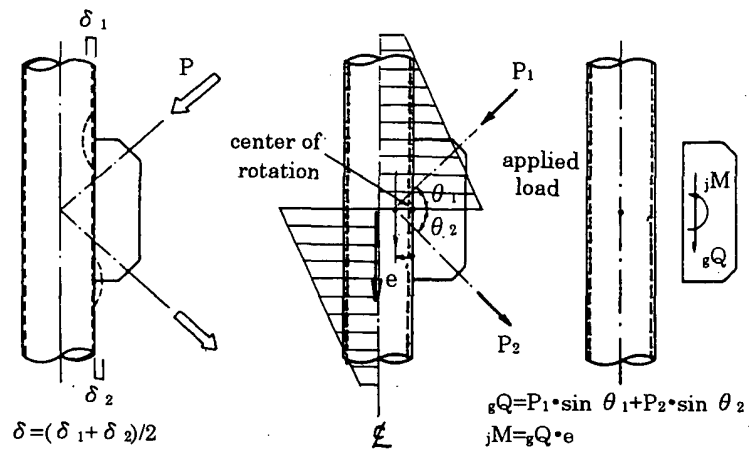

Fig.12 記号説明図 

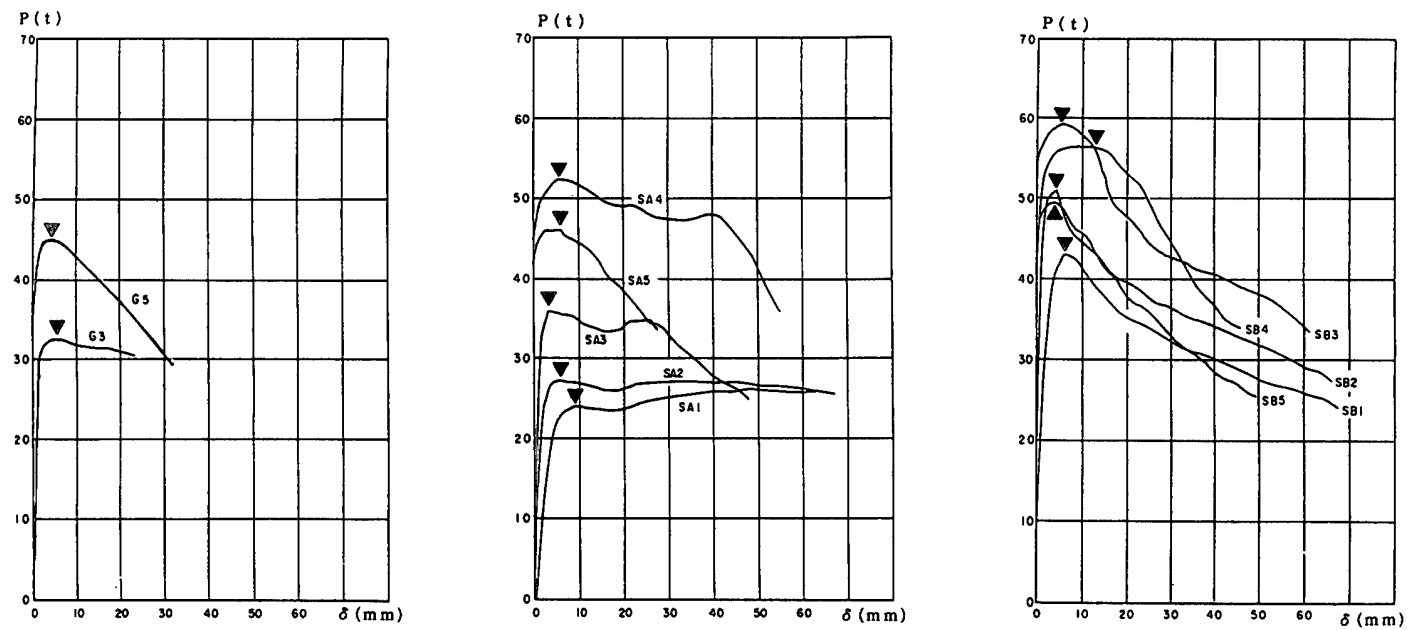

Fig.13 荷重一柱材鎘管局部変形関係

\section{2 荷重一変形関係}

Fig.13 に荷重 $\mathrm{P}$ 一柱材管壁のガセットプレート端部位置における 平均面外変形量 $\delta$ の関係を示す。記号は Fig.12の説明図に做う。

これより，いずれの試験体も，図中印で示す最大耐力点までは ほぼ線形的な挙動を示し, ガセットプレートが付いた接合部内にお いて，压縮端部側補強プレート位置を凹型局部変形の中央、引張側 補強プレート位置を凸型局部变形の中央とした局部变形モードの顕 在化により耐力が低下する。最大耐力は, 偏心量が+(内側引付け) になるほど，また補強度が大きいほど大きくなる傾向を示す。

ただし，十偏心量が大きくかつガセットプレート端部補強度の大 きい試験体は，柱材に作用する偏心曲げモーメントの影響により， ガセットプレート下端直下柱材における局部座屈で屈伏し，接合部 耐力を下回る結果となり，耐力傾向が逆転する。なお，この座屈モ 一ドは, 補強プレート位置が凹型局部変形の上端となり，柱材管壁 局部変形モードとは異なる。

なお，劣化勾配は最大耐力が小さいほど緩やかな傾向を示す。

\section{3 接合部最大耐力の定量的評価}

柱材管壁への作用曲げモーメント $\mathrm{j} \mathrm{M}$, ガセットプレートに生ずる せん断力 ${ }_{\mathrm{g} Q} \mathrm{Q}$ は, それぞれ(4),(5)式で表される。

$$
\begin{aligned}
& { }_{j} M=\sqrt{2} P \cdot|e| \\
& { }_{\mathbf{g}} Q=\sqrt{2} P
\end{aligned}
$$

また, 下部補強プレート位置柱材に作用する軸力 $\mathrm{p} N$ および曲げモ ーメント $\mathrm{p} M$ は(6)式で表される。

$$
\begin{aligned}
{ }_{\mathrm{p}} \mathrm{N} & =\sqrt{2} \mathrm{P} \\
\mathrm{p} & \sqrt{2} \mathrm{P} \cdot\left|\mathrm{e}-\frac{\mathrm{D}}{2}\right| \cdot \frac{\mathrm{L}-\mathrm{B}}{\mathrm{L}} \\
\mathrm{L} & : \text { 試験体長さ } \\
\mathrm{B} & : \text { ガセットプレート長さ }
\end{aligned}
$$

$\mathrm{G}$ シリーズの接合部局部変形最大耐力評価方法として, 作用曲げ モーメントに対し(7-1)1),(7-2)2)式が提案されている。

$$
\begin{aligned}
& j^{\mathrm{M}} \mathrm{M}_{\max }=4.88 \mathrm{~B}\left(1+\frac{\mathrm{B}}{4 \mathrm{D}}\right) \mathrm{T}^{2} \sigma_{\mathrm{y}} \\
& \mathrm{j}^{\mathrm{M}_{\max }}=1.20 \mathrm{~B}\left\{\left(\frac{\mathrm{D}}{2 \mathrm{~T}}\right)^{0.2}+\frac{1.5 \mathrm{~B}}{2 \mathrm{D}} \cdot\left(\frac{\mathrm{D}}{2 \mathrm{~T}}\right)^{-0.1}\right\} \mathrm{T}^{2} \sigma_{\mathrm{y}}
\end{aligned}
$$

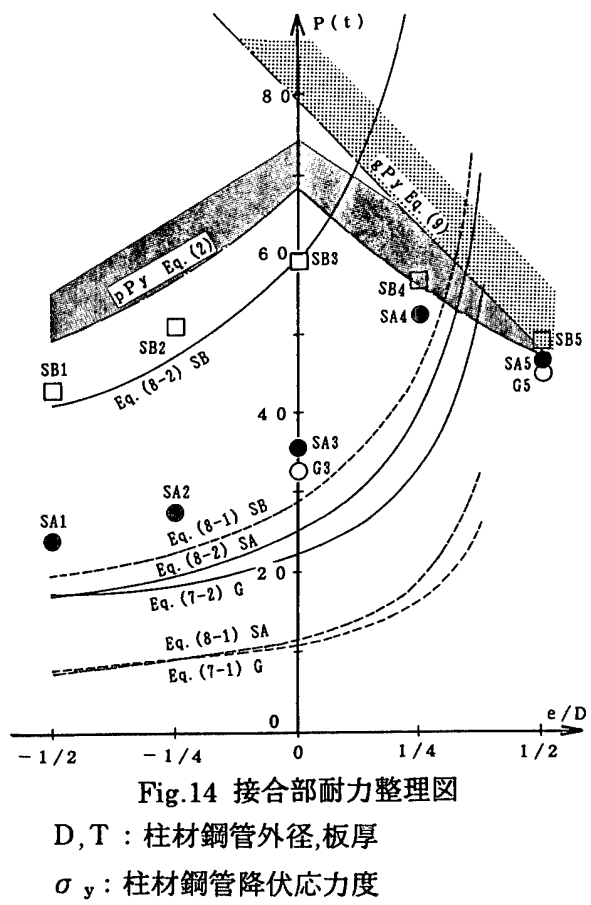

また, SA,SB シリーズについては, (8-1)4),(8-2)2)式が提案されている。

$$
\begin{aligned}
{ }_{\mathrm{j}} \mathrm{M}_{\max } & =6.43 \mathrm{~B}\left\{1+4.60\left(\frac{\mathrm{C}}{\mathrm{D}}\right)^{2}\right\} \mathrm{T}^{2} \sigma_{\mathrm{y}} \\
{ }_{\mathrm{j}} \mathrm{M}_{\max } & =1.60 \mathrm{~B}\left\{1+4.90\left(\frac{\mathrm{C}}{\mathrm{D}}\right)^{2}\right\} \cdot\left(\frac{\mathrm{D}}{2 \mathrm{~T}}\right)^{0.2} \mathrm{~T}^{2} \sigma_{\mathrm{y}} \\
\mathrm{C} & : \text { スチフナプレート幅 }
\end{aligned}
$$

また，ガセットプレートのせん断降伏耐力は(9)式でちえられる。

$$
\begin{aligned}
&{ }_{B} Q_{y}=B \cdot t \cdot{ }_{B} \sigma_{y} / \sqrt{3} \\
& t: \text { ガセットプレート板厚 } \\
&{ }_{g} \sigma_{y}: \text { ガセットプレート降伏応力度 }
\end{aligned}
$$

なお，偏心曲げモーメントが作用する接合部耐力は(2)式より与え られる。

Fig.14 に最大耐力(腹材荷重 P に換算)に関する実験結果と上記設 計式に基づく算定結果との比較図を示す。ここに, 縦軸は腹材荷重 $\mathrm{P}$ を，横軸は偏心量の鋼管外径に対する比 $\mathrm{e} / \mathrm{D}$ とする。 
(5),(9)式より算定される ${ }_{\mathrm{g}} \mathrm{P}_{\mathrm{y}}-\mathrm{e} / \mathrm{D}$ 関係線より上側の灰色ハッチン グした部分は，ガセットプレートのせん断降伏領域を，(2),(6)式より 算定される $\mathrm{p}_{\mathrm{y}}-\mathrm{e} / \mathrm{D}$ 関係曲線より上㑡の黒色ハッチングした部分は 偏心曲げを考虑した柱材鋼管局部座屈領域を示す。また, (4),(7)式, (4),(8)式より算定される図中実線および点線は，G および SA,SB 各 シリーズの接合部局部変形最大耐力評価線を示す。

これより，設計式は統計手法を用いばらつきを考慮している安全 㑡の評価を与える傾向にあるか，偏心曲げモーメントを実態に即し たディテールにより作用させた場合においても，評価式は有効であ ることが確認される。

また，内側偏心，すなわち十偏心で端部補強度が大きい場合には，柱 材鋼管の局部座屈あるいはガセットプレートのせん断降伏で耐力が決定 される傾向にあり，3，2の崩壊モードの結果が裏付けされる形となる。

\section{4. 但心接合の接合部㝗労耐力に及ほすす影要}

\section{1 接合部疲労耐力試験概要}

銅管接合部の疲労耐力に影響を及ばすファクターとして，(1)偏心 量 $\mathrm{e}$ は 5 種類，(2)ガセットプレート端部㭪強方法は 3 種類。(3)応力比 $\mathrm{R}$ は $\mathrm{R}=0$ (完全片振り), $\mathrm{R}=-1$ (完全両振り)の 2 種類とし、試験体総数 はこれらの組合せ，さらに応力振幅を変化させた Table 6 に示す 26 体とする。なお，試験体の形状寸法等の諸元および試験装置は接合 部耐力試験に做う。また，溶接部について，応力集中の楥和あるい は，所定の形状に仕上げるなどの特別な配虑はしないものとする。

なお，送電用鉄塔は風荷重が支配的であることから，本研究では 支配荷重が地震となる構造物に対して検討される領域の低サイクル 疲労は対象外とし，絽返し数が 1,000 回以上となる比較的高サイク ルの領域を対象とする。

\section{2 接合部疲労耐力の定量的評価}

亀裂発生筒所(hot spot)は，Fig.10 に示すように，G シリーズはガセッ トプレート外側，SA,SB シリーズはスチフナ端部の隅肉溶接部となる。

この接合部疲労耐力を評価するにあたって, 亀裂発生箇所の応力 振幅を評価する必要があるが, 試験体種別が多種であり, 応力振幅 の画一的評価が困難である。したがって，本研究では，接合部耐力 試験において柱材が局部座屈した試験体については，局部座屈箇所
と亀裂発生箇所とは部位が異なるものの，文献 1)の支管同士が相関 しない $\mathrm{K}$ 型分岐継手の疲労曲線関係の整理手法に做って，荷重振幅 $\mathrm{Pr}$ を接合部耐力試験における最大耐力 $\mathrm{P}$ max で除すことにより無次 元化した無次元化応力振幅 $\mathrm{P}_{\mathrm{r}} / \mathrm{P}_{\max }$ を用いて整理することにする。

Table 6, Fig.15 に $\mathrm{P}_{\mathrm{r}} / \mathrm{P}_{\max }$ と亀裂発生により載荷不能(疲労寿命) となるまでの繰返し数 $\mathrm{N}_{\mathrm{f}}$ の関係を示す。

ガセットプレート端部補強度, 接合部耐力試験における崩壊モー ドによる大きな差巽は認められない。これは、“無次元化応力振幅の 分母である $P_{\text {max }}$ によってその差異が既に評価されているためと考え られる。これより， $R=-1$ (完全両振り)の方が $R=0($ 完全片振り)に比へ て高い疲労性能を有する評洒となるなど応力比による差異は認めら れるものの，本研究における応力振幅評価は概ね適当である之判断 できる。また，併せて図中実線で示す(10)式に示す回帰直線が求まる。 ちなみに，この直線は図中点線で示す $\mathrm{K}$ 型分岐継手の回帰直線に比 へて約 $60 \%$ 程度の耐力評価となる。

$$
\log _{10}\left(\frac{N_{f}}{10^{6}}\right)=-3.25-3.94 \log _{10}\left(\frac{P_{r}}{P_{\max }}\right)
$$

Table 6 接合部疲労耐力試験結果一覧

\begin{tabular}{|c|c|c|c|c|c|c|}
\hline 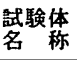 & $\begin{array}{l}\mathrm{Pr} / \\
\mathrm{P} \max \end{array}$ & $\mathrm{R}$ & $\begin{array}{c}\mathrm{Nf} \\
\left(\times 10^{2}\right)\end{array}$ & $\begin{array}{l}\mathrm{Pr}_{\mathrm{r}} / \\
\mathrm{P}_{\max }\end{array}$ & $\mathbf{R}$ & $\left(\begin{array}{c}N f \\
\left(\times 10^{2}\right)\end{array}\right.$ \\
\hline G 3 & 0.76 & -1 & 6 & 0.30 & -1 & 974 \\
\hline G 5 & 0.70 & -1 & 12 & 0.28 & -1 & 2000 \\
\hline S A 1 & 0.43 & 0 & 65 & 0.38 & 0 & 137 \\
\hline S A 2 & $\begin{array}{l}0.43 \\
0.32\end{array}$ & $\begin{array}{l}0 \\
0\end{array}$ & $\begin{array}{r}80 \\
194 \\
\end{array}$ & 0.37 & 0 & 114 \\
\hline S A 3 & $\begin{array}{l}0.84 \\
0.46 \\
0.42\end{array}$ & $\begin{array}{r}-1 \\
-1 \\
0 \\
\end{array}$ & $\begin{array}{r}12 \\
247 \\
110 \\
\end{array}$ & $\begin{array}{l}0.66 \\
0.48\end{array}$ & $\begin{array}{r}-1 \\
0\end{array}$ & $\begin{array}{l}40 \\
50\end{array}$ \\
\hline S A 4 & $\begin{array}{l}0.54 \\
0.40\end{array}$ & $\begin{array}{l}0 \\
0\end{array}$ & $\begin{array}{r}97 \\
265\end{array}$ & 0.47 & 0 & 132 \\
\hline S A 5 & $\begin{array}{l}0.54 \\
0.40 \\
\end{array}$ & $\begin{array}{l}0 \\
0 \\
\end{array}$ & $\begin{array}{r}19 \\
265 \\
\end{array}$ & 0.47 & 0 & 132 \\
\hline S B 1 & 0.47 & 0 & 49 & 0.41 & 0 & 66 \\
\hline S B 2 & $\begin{array}{l}0.47 \\
0.35 \\
\end{array}$ & $\begin{array}{l}0 \\
0\end{array}$ & $\begin{array}{r}71 \\
185 \\
\end{array}$ & 0.41 & 0 & 103 \\
\hline$S$ B 3 & $\begin{array}{l}0.92 \\
0.50 \\
0.46\end{array}$ & $\begin{array}{l}-1 \\
-1 \\
0\end{array}$ & $\begin{array}{r}14 \\
404 \\
170 \\
\end{array}$ & $\begin{array}{l}0.72 \\
0.52\end{array}$ & $\begin{array}{r}-1 \\
0\end{array}$ & $\begin{array}{r}94 \\
120\end{array}$ \\
\hline S B 4 & $\begin{array}{l}0.29 \\
0.23 \\
\end{array}$ & $\begin{array}{l}0 \\
0 .\end{array}$ & $\begin{array}{l}292 \\
613 \\
\end{array}$ & 0.24 & 0 & 703 \\
\hline S B 5 & $\begin{array}{l}0.57 \\
0.42\end{array}$ & $\begin{array}{l}0 \\
0\end{array}$ & $\begin{array}{r}21 \\
226\end{array}$ & 0.50 & 0 & 57 \\
\hline
\end{tabular}

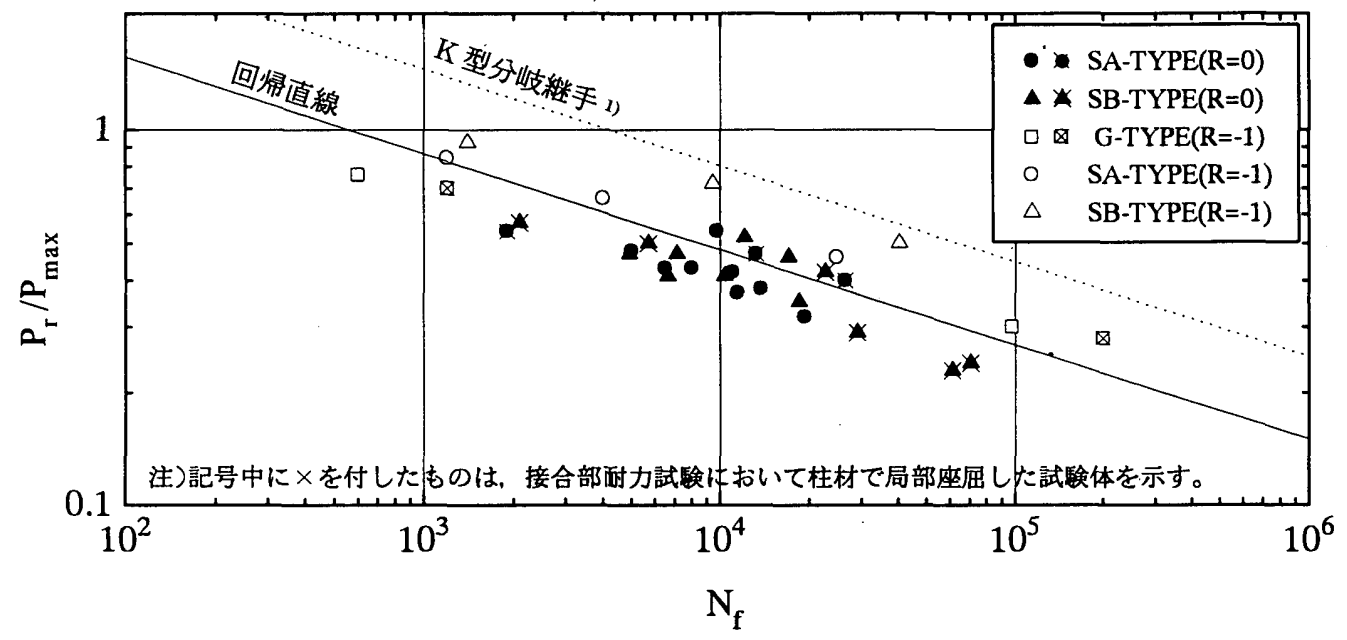

Fig.15 無次元化応力振幅一疲労寿命関係 


\section{5. 結晋}

柱材と腹材を偏心接合させたガセットプレート接合タイプ塔状鋼 管トラス骨組の柱材座屈耐力, 接合部耐力および接合部疲労酎力に 関する本研究において得られた知見を以下に列挙する。

(1)腹材傾斜角度が大きく，かつ細長比が小さい試験体で，部材端 部の局部座屈で屈伏し，偏心曲げモーメントの影響により若干の 耐力低下が認められる。一方，そ机以外の試験体ては，部材中央 部で曲げ座屈を呈し，偏心曲げモーメントによる酎力低下は認め られない。以上より，総して，本研究の範囲では偏心接合によっ て生じる曲げモーメントによる著しい耐力低下は認められない。

(2)偏心接合の柱材座屈耐力に及涩す影蠁は，文献 3)の曲げモーメン 卜を考虑した座屈耐力算定方法を道用することにより定量的に 評価できる。

(3)偏心接合の接合部局部变形耐力に及ほすす影響は，既往の耐力評価 式により安全側に評価てきる。

(4)偏心接合の疲労特性に及ぼす影篦は，本研究の範囲においては， 接合部耐力試験における最大耐力で除した無次元化応力振幅を 䢔用することにより, 偏心量, ガセットプレート端部補強度に関 わらず,ばらつきの少ない形で一律に評価できる。

これらにより，偏心接合を採用する場合の基礎データが概ね整備 されたと拷える。

\section{解 辞}

本研究は, 東京電力株式会社における UHV 送電用鉄塔の総合開発 研究として行われたものであります。ここに，関係各位に梁謝の意 を表します。

\section{『路浩女跌】}

1),2)日本建築学会：鎆管構造設計施工指針・同解説(第 1 版),1980，同(第 2 版), 1990

3)鈴木敏郎，佐藤亘宏，深沢隆：塔状銅管トラス骨組の座屈耐力に関する研 究(細長比の小さい柱材で座屈する場合)、日本建築学会構造系諭文報告集第 425 号, 1991

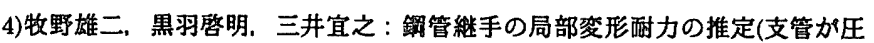
縮力を受ける場合)、日本建築学会桡造系諭文報告集第 251 号，1977

5)M.Fujimoto, H.Yamagishi, N.Satoh and KIzawa : Experimental Study on Ultimate Strength and Low-Cycle Fatigue Resistence of Tube to Gusset Plate K-Joints, Intemational Meeting on Safety Criteria in Design of Tubular Structures, 1986 6)山岸啓利，伊沢健，深沢隆，松尾康博，田沼息一：偏心接合される塔状銅

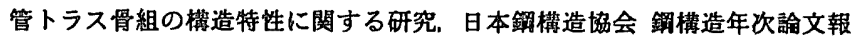
告集第 1 巻, 1993.7 